\title{
OPTIMUM DESIGN OF STEEL STRUCTURES 2013
}

\author{
Jozsef FARKAS, Karoly JARMAI \\ 01 February 2014 Vilnius
}

\section{Review}

The book covers 290 pages made of 8 Chapters, 4 Appendixes, References and Subject Indexes.

The title of the book provides that this study is dedicated to searching solutions for optimum steel structures. For a number of years, the authors timed for the development of design methods regarding optimum steel structures and published several books on this subject. Currently, structural optimization methods have been permanently improved, and the possibilities of computers and their software have increased. Therefore, the suggested new publication is an important event due to the fact it is not an ordinary edition appearing as the only cosmetic dressing up of old books. It is a signally changed piece of writing that has introduced a new mind-set and has been extended with new examples.

The book has consistently applied optimization methods, considered the peculiarities of using them and reviewed the main features such as a minimum weight of structures, the cost of the material and the total cost. The other chapters of this book deal with the problems of the optimum design of practically all types of structures illustrating those with the examples of the solved exercises. Here you can also find the examples of the optimally designed simplest welded box section beams, centrally compressed columns with pinned ends of the welded square box cross-section and more complicated structures like trusses, multi-story frames with V-bracing and portal frames. The book examines less common structures, including welded stiffened plates, cylindrical and conical shells. The last-mentioned examples perfectly describe the possibilities of optimum design methods proving that a variety of the geometry and sections of steel structures do not disturb the application of optimum design methods. An important point is that the methods of structural optimum design studied in this book are covering ultimate and serviceability limit states.

The writing style of the book is quite simple and easily understandable. The Department of Steel and Timber Structures of Vilnius Gediminas Technical University recommends this book to second-cycle (Master's degree) students of the programme Optimal Building Structures.

As the reviewed book is a perfect educational tool, we wish the authors great success in the forthcoming publications.

Dr. Habil. Prof. Audronis Kazimieras Kvedaras

Dr. Assoc. Prof. Gintas Šaučiuvènas

Department of Steel and Timber Structures

Vilnius Gediminas Technical University

Saulètekio al. 11, 10223 Vilnius, Lithuania 